DOI 10.18551/rjoas.2019-01.65

\title{
LAIS FISH STOMACH CONTENT COMPOSITION (CRYPTOPTER SPP.) AND CHARACTERISTICS OF RAWA DANAU PANGGANG SOUTH KALIMANTAN
}

\author{
Sofarini Dini \\ Department of Aquatic Resource Management, University of Lambung Mangkurat \& \\ Post-Graduate Program, Faculty of Fisheries and Marine Sciences, University of Brawijaya, \\ Indonesia
}

\author{
Herawati Endang Yuli, Mahmudi Mohammad, Asus Maizar S.H. \\ Department of Aquatic Resource Management, Faculty of Fisheries and Marine Sciences, \\ University of Brawijaya, Indonesia
}

\author{
Amin Mohamad \\ Department of Biology, Faculty of Mathematics and Sciences, University of Negeri, \\ Malang, Indonesia \\ *E-mail: dini.sofarini@ulm.ac.id
}

\begin{abstract}
The Rawa Danau Panggang (Panggang Lake Swamp) in Hulu Sungai Utara Regency stretches as far as $5,390.7 \mathrm{Ha}$. This swamp has a large ecological, economic and fisheries resource potential. One of its potentials is lais fish (Cryptopter spp) and plankton which are food sources for these fish biota. The purpose of this study was to determine the food composition of fish lais (Cryptopter spp) and the characteristics of Rawa Danau Panggang waters. The research method used analysis of gastric contents with the largest section index based on Natarjan and Jingran in Effendi (2002) and storet methods for supporting water quality data. The research results exhibited that the food composition found in the lais fish stomach (Cryptopter spp) was diverse. Lais fish were classified as omnivores. Phytoplankton groups have 27 genera from 3 phyla, Zooplankton 6 genera from 2 divisions, and Nekton 1 genera from 1 division. The contents of the gastric stomach (Cryptopter spp) are mostly from the phytoplankton group. The highest genus is 5 , namely Navicula with IP $=26.71 \%$, Diatoma with $\mathrm{IP}=20.33 \%$, Tabellaria with $\mathrm{IP}=12.43 \%$ ), and Nitzschia with $\mathrm{IP}=8.54 \%$, which are genera of Phylum Chrysophyta, and Gonatozygon with IP $=5.35 \%$ which is the genera of Phylum Chlorophyta. The zooplankton group consumed by this fish has far less diversity and abundance compared to phytoplankton group. Plankton consumed by lais fish is determined by the characteristics of Rawa Danau Panggang waters. DO, $\mathrm{pH}$ and BOD dominate the characteristics of Rawa Danau Panggang waters.
\end{abstract}

\section{KEY WORDS}

Cryptopter spp, preponderance index, water, quality.

Rawa Danau Panggang (Panggang Lake Swamp) is a wetland ecosystem with a peatland type thick peat (Noor, 2007). It is a water storage area and fish biota habitat. Its associated ecosystems, the peat swamp ecosystem, is characterized by $\mathrm{pH}$ acid, colloidal suspended solids possessing red color and odor aquatic indicators derived from weathering of organic matter. Organic contamination transfer can occur in laminar flow patterns due to input from the Barito River and the Negara River in the rainy season, thus influencing the biota.

Lais Fish (Cryptopter spp) is one type of fish found in the waters of Rawa Danau Panggang. Lais fish are almost always found in each research station. Lais fish are included in the Siluridae family which consists of several genera. The most common genus is Cyptopterus. The lais fish life cycle generally occurs in waters possessing a large amount of 
riparian vegetation. Lais fish is one of the fish possessing important economic value in South Kalimantan Province.

Distribution of lais fish is determined by the food type and food availability in the waters. In general, the number and diversity of fish are determined by the size of the water body, therefore influencing the proportion of fish biomass that depends on its habitat. The amount of food composition will also determine lais fish composition and growth (Arsiyana and Yuliana, 2012; Lukas and Minggawati, 2014). Food availability contained in the waters of Rawa Danau Panggang could be determined by analyzing the food contained in the fish stomach and compare it with food available in the waters.

The purpose of this study was to determine the composition of Lais Fish (Cryptopter spp) and the characteristics of Rawa Danau Panggang waters. Lukas and Minggawati (2014) reported the analysis result of lais fish stomach's food composition. The lais fish were collected from the flood swamps of the Rungan River for four months period. The food material contained in the lais fish stomach was dominated by insect and fish. Handayani (2006) reported that the results of the analysis of food material contained in the Lais Bantut stomach. The fish were collected from Lake Lais. Research result exhibited that the food consisted of various types of organism namely adult insects, insect larvae, small fish, detritus and unidentified material.

\section{METHODS OF RESEARCH}

This research was carried out in the waters of Rawa Danau Panggang, Hulu Sungai Utara Regency. Fish sampling was done every 3 months, namely in July 2017, October 2017, January 2018 and April 2018. The data used in this study were primary data analyzed. The population of the fish studied was Lais fish (Cryptopter spp). Fish samples were collected using net fishing equipment.

The caught fish samples were separated according to the research station. Retrieving fish stomach was done by dissecting the abdominal part starting from the anus to the vertebrae and operculum bone. The stomach was taken and put into a film bottle containing $4 \%$ formalin until it sank into the formalin solution. The sample was taken to the Water Quality and Hydro Bioecology Laboratory of Unlam Faculty of Fisheries and Marine. Furthermore, the composition of the gastric contents was determined using the method of the frequency of events and the volumetric method of gastric contents. The stomach was cut open and sorted according to respective organism content. In order to determine the favored food type, the researcher calculated the Largest Section Index (Index of Preponderance) expressed in percent (Natarjan and Jhingran (1961) in Effendi (2002).

Method of Frequency of Events. Taunay (2012) states that to measure the frequency of events by recording each gastric contents to ensure the stomach contents are divided into two groups, namely the filled stomach and empty stomach:

$$
\mathrm{Oi}=\frac{\mathrm{Ni}}{\mathrm{I}} \mathrm{X} 100 \%
$$

Where: $\mathrm{Oi}=$ Frequency of occurrence; $\mathrm{Ni}=$ The total number of one type of organism; $\mathrm{I}=$ Total filled stomach.

Volumetric Method. The volumetric method aims to measure fish food based on the volume of food contained in the fish stomach:

$$
\mathrm{Vi}=\frac{\% \mathrm{i}}{\mathrm{I}} \mathrm{X} 100 \%
$$

Where: $\mathrm{Vi}=$ Volumetric; $\% \mathrm{i}=$ total volume of one type of organism in percent; $\mathrm{I}=$ Total filled stomach. 
Preponderance Index. This calculation aims to evaluate fish eating habits with a combination of two methods, namely the frequency event method and the volumetric method developed by Natarjan and Jhingran (1961) in Effendi (2002).

$$
\mathrm{IP}=\frac{\mathrm{Vi} \times \mathrm{Oi}}{\Sigma \mathrm{Vi} \times \mathrm{Oi}} \mathrm{X} 100 \%
$$

Where: $\mathbf{l i}=$ Preponderance Index; $\mathrm{Vi}=$ Percentage of volume of food $-\mathrm{I} ; \mathrm{O} \mathrm{i}=$ Percentage of frequency of food occurrence -i.

Analysis of water quality characteristics observed was temperature, brightness, current, $\mathrm{DO}, \mathrm{BOD}, \mathrm{pH}$. Water quality data is calculated using the storet method, taken as supporting data in research, and collected during fish sampling.

\section{RESULTS AND DISCUSSION}

The food consumed by fish can be identified by analyzing the contents of the stomach. Should there are many types of fish food organisms in water, it is not necessarily an important part of the composition of fish food. Nevertheless it could be expressed as an important part in the composition of fish food. Fish choose certain foods, determined by finding the food type as part of the largest food composition (Preponderance Index) in the stomach (Effendi, 2002).

Table 1 - Value of Frequency of Events, Volumetric and Preponderance Composition Indexes of Lais Fish (Cryptopter spp) in Rawa Danau Panggang Waters

\begin{tabular}{|c|c|c|c|c|c|c|}
\hline Phylum & Genera & $\mathrm{Ni}$ & Oi (\%) & Organism Volume & Vi (\%) & IP (\%) \\
\hline \multirow[t]{3}{*}{ Cyanophyta } & Oscillatoria & 11 & 0.73 & 4 & 15.38 & 0.17 \\
\hline & Rivularia & 2 & 0.13 & 1 & 3.85 & 0.01 \\
\hline & Aphanotece & 56 & 3.74 & 8 & 30.77 & 1.72 \\
\hline \multirow[t]{10}{*}{ Chloropyta } & Hormidium & 22 & 1.47 & 7 & 26.92 & 0.59 \\
\hline & Ankistrodesmus & 7 & 0.47 & 2 & 7.69 & 0.05 \\
\hline & Netrium & 33 & 2.20 & 15 & 57.69 & 1.90 \\
\hline & Gonatozygon & 87 & 5.80 & 16 & 61.54 & 5.35 \\
\hline & Oedogonium & 19 & 1.27 & 5 & 19.23 & 0.37 \\
\hline & Geminella & 35 & 2.33 & 14 & 53.85 & 1.88 \\
\hline & Closterium & 40 & 2.67 & 14 & 53.85 & 2.15 \\
\hline & Spirogyra & 19 & 1.27 & 8 & 30.77 & 0.58 \\
\hline & Pediastrum & 7 & 0.47 & 5 & 19.23 & 0.13 \\
\hline & Micrasterias & 2 & 0.13 & 1 & 3.85 & 0.01 \\
\hline \multirow[t]{14}{*}{ Chrysophyta } & Tabellaria & 154 & 10.27 & 21 & 80.77 & 12.43 \\
\hline & Navicula & 331 & 22.08 & 23 & 88.46 & 26.71 \\
\hline & Frustulia & 34 & 2.27 & 13 & 50 & 1.70 \\
\hline & Fragillaria & 68 & 4.54 & 15 & 57.69 & 3.92 \\
\hline & Coconeis & 32 & 2.13 & 11 & 42.31 & 1.35 \\
\hline & Diatoma & 230 & 15.34 & 21 & 80.77 & 20.33 \\
\hline & Eunotia & 12 & 0.80 & 7 & 26.92 & 0.32 \\
\hline & Dentiluca & 1 & 0.07 & 1 & 3.85 & 0.00 \\
\hline & Stauroneis & 12 & 0.80 & 6 & 23.08 & 0.28 \\
\hline & Surirella & 58 & 3.87 & 19 & 73.08 & 4.23 \\
\hline & Corethron & 2 & 0.13 & 2 & 7.69 & 0.02 \\
\hline & Synedra & 37 & 2.47 & 12 & 46.15 & 1.71 \\
\hline & Ghomponema & 19 & 1.27 & 11 & 42.31 & 0.80 \\
\hline & Nitzschia & 101 & 6.74 & 22 & 84.62 & 8.54 \\
\hline \multirow[t]{5}{*}{ Protozoa } & Phacus & 31 & 2.07 & 17 & 65.38 & 2.03 \\
\hline & Clamydomonas & 8 & 0.53 & 7 & 26.92 & 0.22 \\
\hline & Asteromonas & 4 & 0.27 & 3 & 11.54 & 0.05 \\
\hline & Euglena & 11 & 0.73 & 8 & 30.77 & 0.34 \\
\hline & Uroglena sp & 2 & 0.13 & 1 & 3.85 & 0.01 \\
\hline Aschelminthes & Notholca & 5 & 0.33 & 4 & 15.38 & 0.08 \\
\hline Chordata & Osteochilus & 7 & 0.47 & 1 & 3.85 & 0.03 \\
\hline
\end{tabular}


Organisms found in the body of Lais Fish (Cryptopter spp) are dominated by phytoplankton organisms as their main food. There is a small number of zooplankton and nekton organisms. This means that lais fish are classified as omnivorous. According to Affandi (1992), the size of fish feed is determined by considering the size of the body and fish's mouth opening. The larger the size of the fish and the opening of the fish mouth, the greater the size of the feed. Natural fish food is usually in the form of plankton, moss, worms, snails, shrimp, and fish. Other types of fish food can be observed from the length of the intestine. Fish with intestinal length $3-7$ times their body length are herbivores. Fish with intestinal length equal to body length are carnivores (Effendi, 2002).

The results of the gastric surgery from 26 gastric contents exhibited that most of the lais fish caught in the waters of Rawa Danau Panggang consumed phytoplankton organisms from the Navicula genera. The value of the volumetric measurements of Navicular phytoplankton organisms reached $88.46 \%$. The volume of Navicular phytoplankton organisms measured in all samples reached $23 \mathrm{ml}$. This exhibited that the phytoplankton Navicula organism is the main food for lais fish caught in the waters of Rawa Danau Panggang. Effendi (2002) states that differences in the number of food organisms eaten by fish occur due to differences in the distribution of organisms in each region. Factors affecting the preferences of aquatic organisms on food are the spread of food organisms, food availability, fish preference, and aquatic environmental factors.

The following is the Preponderance Index Chart of the contents of the lais fish stomach (Cryptopter spp) in July 2017, October 2017, January 2018 and April 2018:

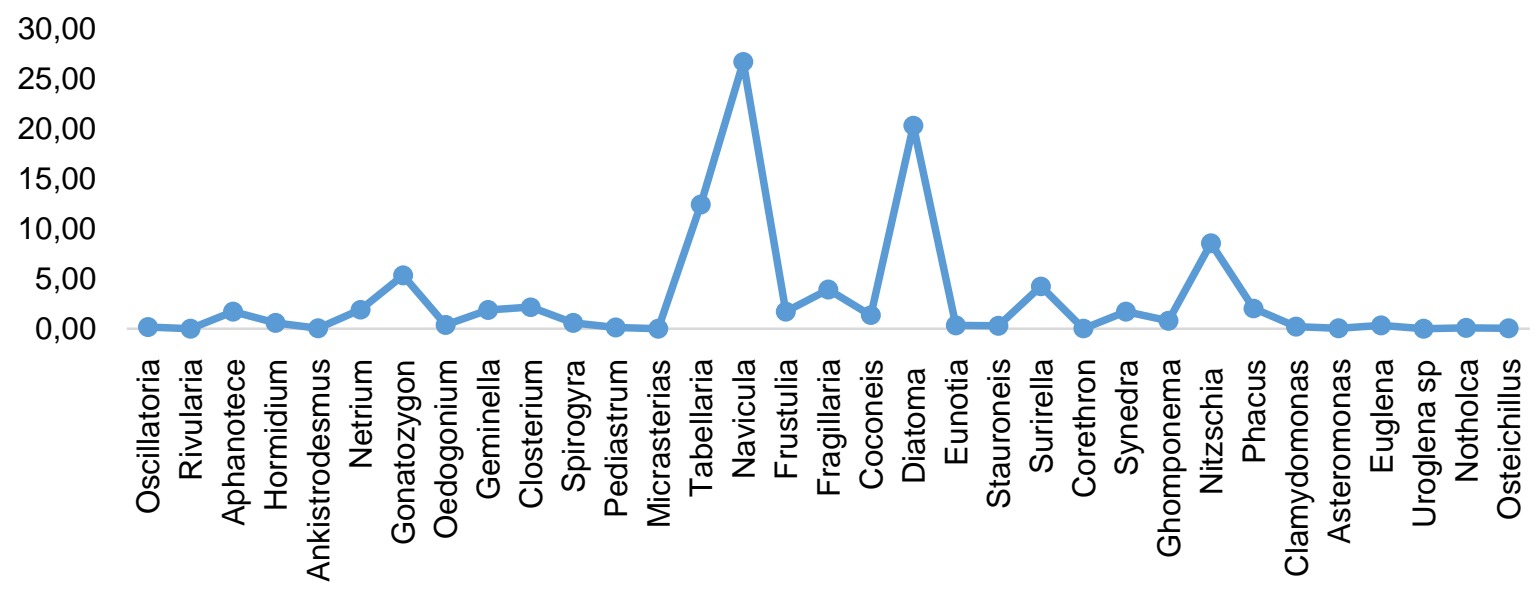

Figure 1 - Percentage of total fish index of preponderance (Cryptopter spp)

The food composition found in the stomach of the Lais Fish is quite diverse. The phytoplankton group has 27 genera from 3 phyla, Zooplankton 6 genera from 2 divisions, and Nekton 1 genera from 1 division. Figure 1 exhibited that most gastric contents (Cryptopter spp) are from phytoplankton groups. The highest genus is 5 , namely Navicula with IP $=26.71 \%$, Diatoma with $I P=20.33 \%$, Tabellaria with IP $=12.43 \%$ ), and Nitzschia with IP $=8.54 \%$, which are several genera from Phylum Chrysophyta, and Gonatozygon with IP $=5.35 \%$ which is the genera of Phylum Chlorophyta. Effendi (2002) stated that the primary food ranges from $>25 \%, 4-25 \%$ is complementary feed, and $<4 \%$ is additional food. Therefore phytoplankton Navicular organisms are the primary foods of Lais Fish. Phytoplankton Diatoma organisms, Tabellaria, Nitzschia, and Gonatozygon are complementary foods. Other phytoplankton, zooplankton and nekton organisms are additional foods.

Lais fishes were caught in sampling I, II and IV, namely in July 2017, October 2017 and April 2018. In sampling III, namely in January 2018, lais fish were not caught in fishing nets. Figure 2 exhibited that food from the group of Navicular phytoplankton organisms is always found in the stomach of the fish for each sampling period. However, there were differences in 
the composition of the lais fish food for each sampling. The largest percentage in July and October 2017 were phytoplankton Navicular organisms (IP $=32.89 \%$ and IP $=27.61 \%$ ), while in April 2018 the largest percentage was Diatoma phytoplankton organisms (IP = $18.44 \%$ ). The two phytoplankton genera are from Phylum Chrysophyta.

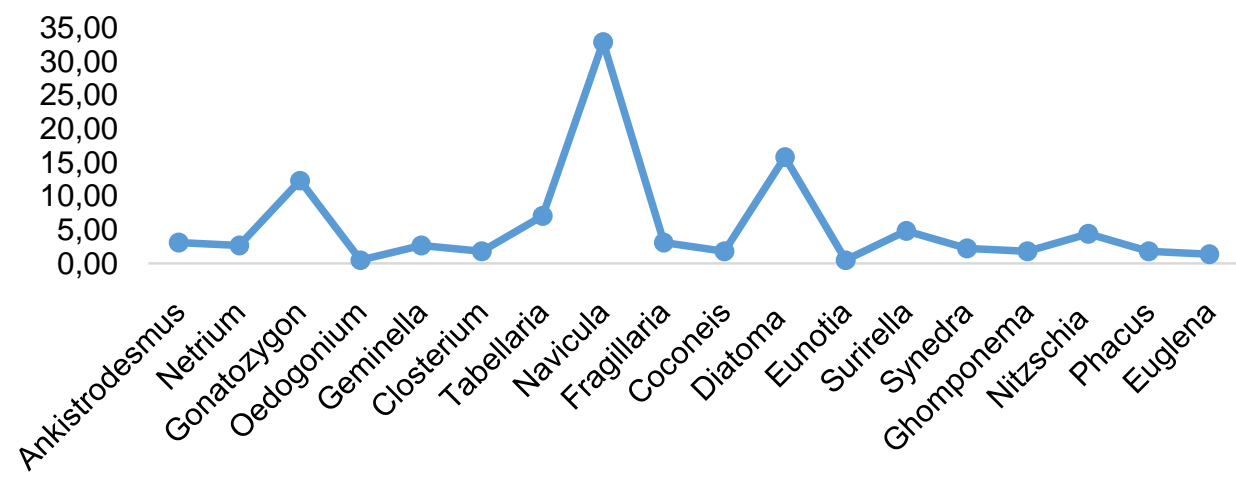

October 2017

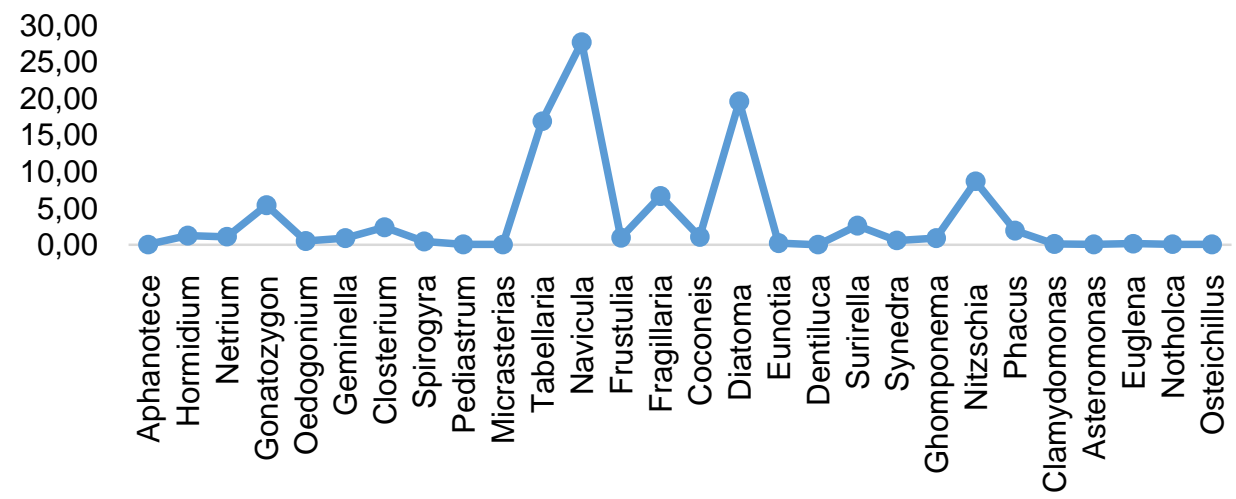

Sampling 4
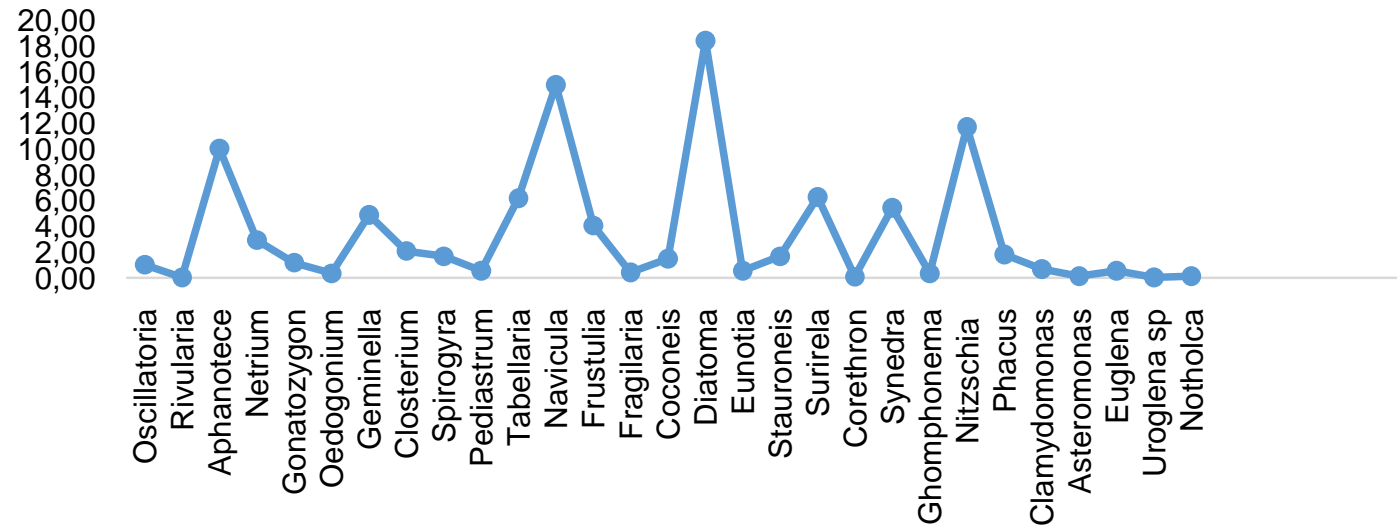

Figure 2 - Temporal Percentage of Lais Fish Preponderance Index (Cryptopter spp)

Phytoplankton organisms from Phylum Cyanophyta and Chlorophyta, groups of zooplankton organisms from Phylum Protozoa and groups of nekton (fish) organisms from Phylum Chordata are the smallest percentage group of Lais Fish composition. Oedogonium from Phylum Chlorophyta is the smallest percentage food group (0.44\%) in July 2017. Rivularia from phytoplankton group Cyanophyta and Uroglene phyla zooplankton from Phylum Protozoa is the smallest group of Lais Fish food, $0.05 \%$ respectively. 
Based on the highest percentage of food types, the primary food of lais fish is Navicula phytoplankton organisms from Phylum Chrysophyta. The differences of food composition in the fish stomach on each sampling period are very closely related to the food availability in nature and environmental conditions. Fish could consume natural foods, such as phytoplankton, which are in the waters. Lais fish are omnivores, hence they eat plankton, aquatic plants, and small fish.

Table 2 - Average Value of Water Quality Parameters

\begin{tabular}{lllllll}
\hline No & Water Quality & July 2017 & October 2017 & January 2018 & April 2018 & PP No 82 2001 \\
\hline 1 & Temperature $\left({ }^{\circ} \mathrm{C}\right)$ & 30.9 & 29.97 & 28.68 & 30.49 & Deviation 3 \\
2 & Clarity $(\mathrm{cm})$ & 41.75 & 35 & 56.17 & 39 & - \\
3 & Current Speed (m/second) & 0.06 & 0.08 & 0.08 & 0.05 & - \\
4 & DO (ppm) & 4.21 & 3.63 & 2.3 & 2.93 & 3 \\
5 & BOD (ppm) & 19.72 & 22.67 & 28.9 & 23.12 & 6 \\
6 & pH & 6 & 6.1 & 5.22 & 5.13 & $6-9$ \\
7 & Nitrate (ppm) & 0.14 & 0.14 & 0.22 & 0.28 & 20 \\
8 & Posfat (ppm) & 0.11 & 0.25 & 0.45 & 0.16 & 1 \\
\hline
\end{tabular}

Peat swamp ecosystem experiences a period of deep water during the rainy season and shallow water during the dry season. According to Junk and Wantzen (2004), these depth fluctuations are due to the overflow of rivers, lakes and/or rainwater. Rawa Danau Panggang depth fluctuation is due to overflow of water from the Barito River and the Negara River during the rainy season. Water quality conditions during sampling of lais fish for July 2017, October 2017, January 2018 and April 2018 (sampling I, II, III and IV), is exhibited in Table 2.

Based on the water quality data, the average temperature in all sampling still exhibited sufficient temperature conditions for fish life $\left(28.68-30.9^{\circ} \mathrm{C}\right)$. This is also supported by Boyd and Kopler 1964 in Buchar (1998) that the optimum temperature for fish growth in the tropics is $20-30^{\circ} \mathrm{C}$. Temperature is one of the parameters of the aquatic environment that affects aquatic biota physiological functions (Effendi, 2003; Muliadi, 2011). The average flow velocity in all sampling also was not significantly different $(0.05-0.08 \mathrm{~m} / \mathrm{sec})$. Flow is relatively slow because swamp waters are classified as closed waters and its currents depend on the wind. The water supply from the Barito River and the Negara River does not significantly affect the currents in Rawa Danau Panggang.

Water clarity is also influenced by the rainfall during water sampling. Changes in seasonal water clarity affect the condition of water quality (Hartoto, 2000; Effendi, 2003), and the rhythms of fish life (Lukas and Minggawati, 2014). The highest clarity occurs in January $2018(56.17 \mathrm{~cm})$ during the rainy season. The lowest clarity occurs in October $2017(35 \mathrm{~cm})$ during the transition from the dry season to the rainy season. The rainy season causes increase water level due to rainwater and river water flowed from the Barito River and the Negara River. Water depth also affects water clarity. The season transition causes turbulence and lifts sedimentation at the bottom of the river, therefore the waters become cloudy.

$\mathrm{DO}$ and $\mathrm{pH}$ values are directly proportional. $\mathrm{DO}$ and $\mathrm{pH}$ in July $(4.21 \mathrm{ppm}$ for $\mathrm{DO}$ and 6 for $\mathrm{pH}$ ) and October 2017 (3.63 ppm for $\mathrm{DO}$ and 6.1 for $\mathrm{pH}$ ) meet Water Quality Standards based on PP No. 82 of 2001 . July and October is the dry season period, hence there is no rain supply affecting dissolved oxygen conditions. The $\mathrm{pH}$ of peat swamp waters tend to be acidic (Center for Agricultural Land Research and Development, 2008). The value of BOD at all sampling period does not meet water quality standards as each exceed the water quality standard (>6 ppm). Whereas nitrate and phosphate values at all sampling periods metwater quality standards ( $<20 \mathrm{ppm}$ for nitrates and $<1 \mathrm{ppm}$ for phosphate).

Analysis of water quality data as supporting data of this study exhibited that the characteristics of Rawa Danau Panggang waters are dominated by DO, pH and BOD factors. The characteristics of Rawa Danau Panggang waters also determine the presence of plankton which is a food source for lais fish (Cryptopter spp). 


\section{CONCLUSION}

The food composition in the lais stomach (Cryptopter spp) is mostly phytoplankton Navicula organisms from Phylum Chrysophyta. Navicules are almost always found in all of the filled fish stomachs at all sampling period. Volumetric measurements reached $88.46 \%$ and the average Preponderance Index (IP) was $26.71 \%$. Therefore phytoplankton Navicula organisms from Phylum Chrysophyta is the main food of Lais Fish (Cryptopter spp).

Temporal food composition exhibited in July 2017 is dominated by Navicula (IP = $32.89 \%$ ), October 2017 is also dominated by Navicula (IP = 27.61\%), and April 2018 is dominated by Diatoms (IP $=18.44 \%$ ). The two phytoplankton genera are from Phylum Chrysophyta. In January 2018 lais fish were not caught in fishing nets.

Analysis of water quality data as supporting data of this study exhibited that the characteristics of Rawa Danau Panggang waters are dominated by DO, pH and BOD factors. The characteristics of the Rawa Danau Panggang waters also determine the presence of plankton which is a food source for lais fish (Cryptopter spp).

\section{ACKNOWLEDGEMENTS}

The author expresses his deepest gratitude to the DRPM Kemenristekdikti for the Doctoral Dissertation Grant scheme, which has financed this research to completion and to the Doctoral Program in Fisheries and Marine Sciences, University of Brawijaya.

\section{REFERENCES}

1. Affandi,R., D.S. Sjafei, M.F. Rahardjo, Sulistiono. 2005. Fisiologi ikan, pencernaan dan penyerapan makanan. Departemen Manajemen Sumberdaya Perairan, Fakultas Perikanan dan IImu Kelautan, Institut Pertanian Bogor, Bogor.

2. Asriyana., Yuliana. 2012. Produktivitas Perairan. Bumi Aksara, Jakarta. 278 hal.

3. Balai Besar Penelitian dan Pengembangan Sumberdaya Lahan Pertanian. 2008. Pemanfaatan dan Konservasi Ekosistem Lahan Rawa Gambut di Kalimantan. Jurnal Pengembangan Inovasi Pertanian 1 (2): 149-156.

4. Buchar T, 1998. Bioekologi amunitas Di Danau Sabuah Kabupaten Kapuas Pronvinsi Kalimantan Tengah.Tesis Program Pascasarjana Institut Pertanian Bogor.

5. Effendi, M.I. 2002. Biologi Perikanan. Yayasan Pustaka Nusantara, Jakarta.

6. Effendi, M.I. 2003. Assessing Water Quality Management for Water Resources and Environment. Canisius, Yogyakarta. KISP.

7. Handayani. 2006. Apek Biologi Ikan Lais di Danau Lais. Journal of Tropical Fisheries (2 006) 1(1): 12-23.

8. Hartoto, D.I. 2000. Relationship of water level to water quality in an oxbow lake of Central Kalimantan. Proceedings of the International Symposium on Tropical Peeadland. Bogor 22-23 November 1999.

9. Junk, W.J. 2004. The flood pulse concept: new aspects, approaches, and applications-an update. In: Welcomme R, and T. Petr. (ed.). Proceedings of the Second International Symposium on the Management of Large Rivers for Fisheries Volume II, FAO Regional Office for Asia and the Pacific, Bangkok, Thailand. RAP Publication 2004/17.

10. Lukas, Minggawati, I. 2014. Feed Type Percentage in the Stomach of Lais Fish (Ompok hypophthalmus) In Rungan Swamp River, Palangka Raya City. Jurnal of Ziraa'ah. Vol.39 No 3. 100-104.

11. Muliadi H. A. 2011. Distribusi dan Kelimpahan Cladocera (Penelia avirostris DANA,1852) Di Perairan Pesisir Teluk Ambon, Maluku. Oceanologi dan Limnologi di Indonesia. Nomor 37 , volume 2.

12. Noor, M. 2007. Lebak Swamp, Ecology, and Its Using, PT. Raja Grafindo Persada.

13. Taunay, P. N. 2012. Studi Komposisi Isi Lambung dan Kondisi Morfometri Untuk Mengetahui Kebiasaan Makan Ikan Manyung (Arius thalassinus) yang Diperoleh di Wilayah Semarang. Journal Of Marine Research. Vol. 2, No. 1, Tahun 2013, (95): 1-9. 